\title{
Synthesis of Environmental Research Knowledge: The Case of Paraguayan Pantanal Tropical Wetlands
}

\author{
Luca Eufemia ${ }^{1,2}$, Michelle Bonatti ${ }^{1,2}$ \& Stefan Sieber ${ }^{1,2}$ \\ ${ }^{1}$ SusLAND: Sustainable Land Use in Developing Countries Leibniz-Centre for Agricultural Landscape Research \\ (ZALF), Eberswalder Str. 84D 15374 Müncheberg, Germany \\ ${ }^{2}$ Humboldt-Universität zu Berlin, Unter den Linden 6, 10099 Berlin, Germany \\ Correspondence: Luca Eufemia, SusLAND: Sustainable Land Use in Developing Countries Leibniz-Centre for \\ Agricultural Landscape Research (ZALF), Eberswalder Str. 84D 15374 Müncheberg, Germany. Tel: \\ 49-3343-2820. E-mail: luca.eufemia@zalf.de
}

Received: July 25, 2018 Accepted: August 17, 2018 Online Published: October 17, 2018

doi:10.5539/sar.v7n4p125 URL: https://doi.org/10.5539/sar.v7n4p125

\begin{abstract}
The Paraguayan Pantanal offers a valuable case of research regarding natural resource management in tropical wetlands. It is one of the world's largest wetland of globally important ecological and cultural value that is threatened from environmental exploitations. Paradoxically, this area is rarely scientifically investigated. Therefore, in this paper, this case was chosen to identify literature indirectly related to the area and to highlight the dominant research trends and corresponding gaps. This research was conducted to cluster the available science-based research of Pantanal's tropical wetlands in order to advocate for more environmental governance focus. Concepts used in the scientific literature of the Paraguayan Pantanal were extrapolated and summarized in category system. A cluster framework of 12 variables of community-based natural resource management (CBNRM) was classified into three main search-categories: community engagement and participatory approach (CEPA), natural resources management (NRM) and framework developed (FD). The frequency of different categories demonstrates the natural science's perspectives dominate over human sciences and humanities. Most of the Paraguayan Pantanal has been studied with regard to its ecological, biological and physical properties. The development of research interest over time and the primary focus on ecological baseline conditions are related to its designation as a Ramsar Site, an UNESCO tentative World Heritage Site and the orientation of national policies towards either environmental protection or regional economic development. A substantial research gap was identified in the FD as studies tended to link their findings to human activities but disregarded the connection between governance variables, natural resource and environmental developments. It is suggested to expand the natural science's perspective on Paraguay's wetlands to account for economic, social and political aspects in order to develop a holistic and environmentally sustainable production of science in and about the area.
\end{abstract}

Keywords: community-based natural resource management, community-governance, literature analysis, Pantanal, Paraguay

\section{Introduction}

Science based-researches on environmental sustainability have generated numerous theories and principles about the use and management of natural resources worldwide. In the context of South American tropical wetlands, a literature analysis of the Paraguayan Pantanal was chosen because of its global relevance as Wetlands of International Importance (known also as Ramsar Site) and a potential candidate within UNESCO World Heritage List Nominations (WWF, 2016a, 2016b). With a surface area of over 230.000 square kilometres the Pantanal is the world's largest freshwater wetland system (Swarts, 2000; WWF, 2016). This ecoregion is considered one of the most biodiverse places in the world and includes countries of Brazil, Bolivia and Paraguay. The Paraguayan Pantanal is 5 to $10 \%$ of the area and includes a great variety of flora and fauna. There are 650 different birds, 240 fish species, 60 species of amphibians and 100 reptiles, at least 120 mammal species and 1,700 plant species (Horton, 2010; WWF, 2016). Besides, ethnographic, cultural and historical principles and values are core factors of the richness of the Pantanal.

The expansion of agroindustry, extensive overgrazing, distribution and insecurity of land tenure, cattle ranching, 
unsustainable infrastructure development, weak enforcement of laws, as well as the lack of awareness of civil society are the main threats to biodiversity conservation and local communities (WWF, 2016). Yet most science-based literature disregards such topics, limiting the scenario for inclusive and comprehensive strategies for environmentally sustainable development. Governance studies are needed in the region, not only to complement existing research strands but also to create a science network and a platform for expert exchange. Because of the key role of community-based governance models to generate, describe and investigate frameworks for environmental sustainability, the political ecological approach is focused on the theory of community-based natural resource management (CBNRM). Despite the importance of concepts that describe key factors for using and managing natural resources (Ostrom, 1990; Sarker \& Itoh, 2001; Quinn et al., 2007; Sattler et al., 2016), CBNRM theory contains characteristics that constitute a distinctive way of using and managing natural resources. In the last two decades, these characteristics have been the subject of a robust set of literature and have contributed to frameworks for sustainable development (Agrawal \& Gibson, 1999; Armitage, 2005; Bradshaw, 2003; Leach, Mearns, \& Scoones, 1999; Olsson, Folke, \& Berkes, 2004).

Table 1 displays a concise matrix of 12 CBNRM organisational characteristics or variables developed and applied by Gruber that are used here as a set of essential and resumed variables in order to develop this study (Gruber 2010, 2018 n.d.). These 12 principles guided the study and support the legitimacy of the findings. Besides, what functions as the overall hypothesis is the basic assumption that local communities are considered the best resource managers for their closeness, greater knowledge and dependency of natural resources (Agrawal \& Gibson, 1999). For this reason, CBNRM is crucial for science works of environmental sustainability. Hitherto, there is no available science-based literature on CBNRM in the study-area. Therefore, in order to fill this gap, literature was clustered from correlated research areas. These included natural sciences (both life and physical sciences), human sciences and humanities. By digging into selected literature searches to find the existence, role or prevalence of the 12 CBNRM variables, the objective was twofold: (a) to investigate the dominant research trends and (b) to identify the research gaps.

Table 1. The Organisational Principles of CBNRM

\begin{tabular}{ll}
\hline 1. & Public Participation and Mobilisation \\
2. & Social Capital and Collaborative Partnerships \\
3. & Resources and Equity \\
4. & Communication and Information Dissemination \\
5. & Research and Information Development \\
6. & Devolution and Empowerment including Establishing Rules and Procedures \\
7. & Public Trust and Legitimacy \\
8. & Monitoring, Feedback, and Accountability \\
9. & Adaptive Leadership and Co-Management \\
10. & Participatory Decision-Making \\
11. & Enabling Environment: Optimal Pre or Early Conditions \\
12. & Conflict Resolution and Cooperation \\
\hline
\end{tabular}

Source: Gruber 2010

\section{Methodology}

A comparative analysis of applied concepts used in prior science-based literature of the Paraguayan Pantanal was applied. The first screening of science-based literature was done from the 1970s until early 2018. Eleven studies between 1995 and 2010 were identified as most significant for their focus on the area, the scientific relevance and the availability. These are listed in Annex 1. They were collected via online database, such as google scholars and science direct, as well as via national literature archives in both English and Spanish. A key words search included terms like: Pantanal, Wetland conservation, Community-based governance, natural resource governance. A cluster framework to classify the 12 CBNRM variables into three categories was designed based on concentration of key governance concepts. This is shown in Table 2. The search-categories are also shown in Figure 1.

First, a search into the literature on community engagement and participatory approach (CEPA) was carried out in order to learn about the impact of natural resource's degradation and exploitation on local communities. The scenario analysis depicted multidisciplinary case studies as well as the integration of stakeholder views and values. This requisite often leads to the development of integrated knowledge for alternative development models or policy-recommendations. The second category searched was on natural resource management (NRM), 
both renewable and non-renewable, of the Paraguayan Pantanal with regard to its ecosystem services it provides and its ecological, biological and physical properties. From this, the intrinsic link to the intensiveness of the exploitation of Pantanal's natural resources, was deduced. The human impact over the Pantanal was a key element of this search, as well as the related health of the resources found in the area. Thirdly, the expected outcomes of the analysed literature searches were to be the frameworks developed (FD), if any. Systems of legal, economic, policy, social, and environmental frameworks could help scaling up proactive solutions for CBNRM models. In the context of governance, it was hypothesized that literature searches would show the way to maintain and sustainably manage both landscapes and livelihoods of local communities.

Table 2. Search-categories: Gruber's 12 principles of CBNRM

\begin{tabular}{lll}
\hline & & Categories \\
\hline 1. & Public Participation and Mobilization & CEPA \\
2. & Social Capital and Collaborative Partnerships & CEPA \\
3. & Resources and Equity & NRM \\
4. & Communication and Information Dissemination & FD \\
5. & Research and Information Development & FD \\
6. & Devolution and Empowerment including Establishing Rules and Procedures & CEPA \\
7. & Public Trust and Legitimacy & CEPA \\
8. & Monitoring, Feedback, and Accountability & FD \\
9. & Adaptive Leadership and Co-Management & NRM \\
10. Participatory Decision-Making & CEPA \\
11. Enabling Environment: Optimal Pre or Early Conditions & CEPA \\
12. Conflict Resolution and Cooperation & NRM \\
\hline
\end{tabular}

Source: Author's own elaboration

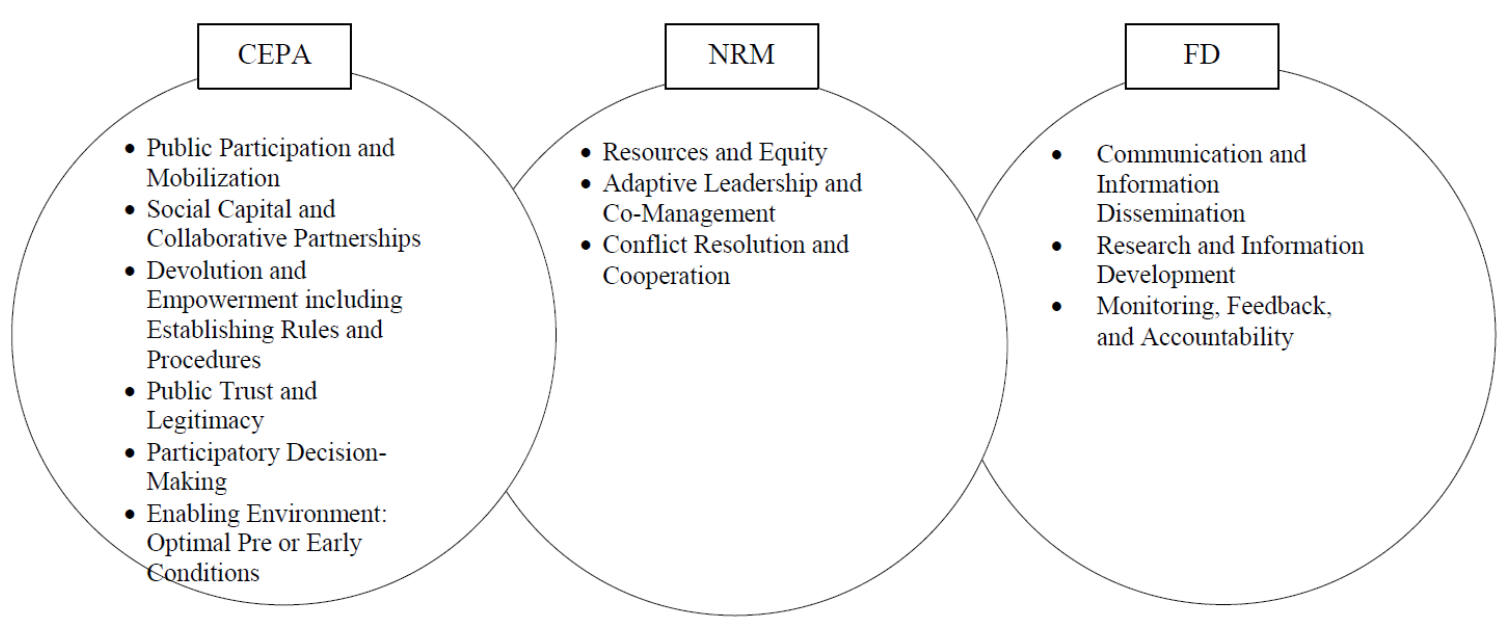

Figure 1. Concentration of key governance concepts

Source: Author's own elaboration

\section{Results and Discussion}

The results offer the list of issues of analysis, the research trends and the frame of the three categories applied in this study: CEPA, NRM and FD, as shown in Table 3. Five out of the eleven researches prioritized on natural sciences (both life and physical sciences), that resulted to be the major research trend. The main gaps were found in the production of frameworks (FD). The following discussion is divided in three main blocks according to the category distribution applied in this study: CEPA, NRM and FD. 
Table 3. Category distribution results

\begin{tabular}{|c|c|c|c|c|c|c|}
\hline Authors & Year & Issue of analysis & Research Trend & CEPA & NRM & FD \\
\hline Blaser, M. & 2009 & Community-Indigenous & $\begin{array}{c}\text { Human Sciences } \\
\text { Humanities }\end{array}$ & $\sqrt{ }$ & $\sqrt{ }$ & - \\
\hline Blaser, $\mathrm{M}$. & 2010 & Community-Indigenous & $\begin{array}{c}\text { Human Sciences } \\
\text { Humanities }\end{array}$ & $\sqrt{ }$ & - & $\sqrt{ }$ \\
\hline Danilo A. et al. & 2004 & Biodiversity-Environment & Natural Sciences & - & $\sqrt{ }$ & $\sqrt{ }$ \\
\hline DGEEC & 2004 & Community-Indigenous & Humanities & - & $\sqrt{ }$ & $\sqrt{ }$ \\
\hline IDEA & 2002 & Economy-Environment & Natural Sciences & $\sqrt{ }$ & $\sqrt{ }$ & - \\
\hline Hetherington, $\mathrm{K}$. & 2009 & Economy-Environment & Humanities & - & $\sqrt{ }$ & - \\
\hline Horton Emily Y. & 2010 & Environment & $\begin{array}{l}\text { Natural Sciences } \\
\text { Human Sciences }\end{array}$ & - & $\sqrt{ }$ & - \\
\hline Susnik, B. & 1995 & Community-Indigenous & Human Sciences & $\sqrt{ }$ & - & - \\
\hline $\begin{array}{l}\text { Swarts Frederick A. } \\
\text { Selected Discourses }\end{array}$ & 2000 & Economy-Environment & Natural Sciences & $\sqrt{ }$ & $\sqrt{ }$ & - \\
\hline Swarts Frederick A. & 2000 & Economy-Environment & Natural Sciences & - & $\sqrt{ }$ & - \\
\hline $\begin{array}{l}\text { Zanardini, J., } \\
\text { Biedermann, W. }\end{array}$ & 2001 & Community-Indigenous & $\begin{array}{c}\text { Human Sciences } \\
\text { Humanities }\end{array}$ & - & - & $\sqrt{ }$ \\
\hline
\end{tabular}

Source: Author's own elaboration

Table 4 lists researches and studies where relevant contribution to CEPA was found. It was observed that recurrent and common elements of the studies included the role of public participation and mobilization. The four selected studies described and included multi-stakeholder approaches, as well as community and identity patterns found in the Pantanal. These form key aspects of effective local and inclusive participation, which can empower community-members, raise knowledge levels and build or increase public trust, confidence and legitimization (Gruber, 2010). Hints of social capital and collaborative partnerships were found in the literature-description of networks. Examples of community-relationships can be depicted in the study and description of the Yshiro (Chamacoco) indigenous community living in study-area. Their practices and visions of life and the world (called the yrmo) are connected to the Yshiro myth-history. For them, as stated by Blaser $(2010,33)$ "the backbone of reality is constituted by relations in a permanent state of flux". From this, additional hypothesis and suggestions for further researches might emerge. For instance, "how to include indigenous Cosmo-visions into projects of environmental sustainability?" or "what formal and informal social norms exist to increase relationships and networking in the area of study?" Stakeholders' mutual understanding and agreements at multi-level scales are presented in the CEPA literature as an important contribution to long-term sustainable development strategies.

In addition, two out of four studies also described and analysed the role of multilevel governance and cross-scale coordination for NRM. Alongside the focus of rural and indigenous communities, these science-based works promoted public and community initiatives, such as the creation of side-projects on sustainable production and marketing of honey and craft products, among others (IDEA, 2002). In the socio-institutional context of the Paraguayan Pantanal, these researches offer notions of authority devolution and empowerment as they claim for decentralization of power and decision making. Multiple layers of governments and initiatives related to the role of decision making, monitoring, conflict resolution and governance are often mentioned to advocate for the creation of clear rules that can help empowering local communities. Cases of stakeholders' sharing power and responsibilities are presented as forms of devolution of authority and responsibility. In the construction on sustainable development, the inclusion and representation of all groups (including the most marginalised) is very important in order to create or modify formal and informal rules and norms (Gruber, 2010). The socio-economic approach of the selected CEPA literature presents a first analysis of the situation and the subsequent development of solutions designed by multi-stakeholder initiatives (Swarts, 2000; IDEA, 2002). Likewise, social and community-based strategies are grounded in the identification of leaders, fostering the formation of groups capable of representing the community and supporting its transformation within formal institutions (e.g. municipalities) and informal ones (e.g. neighbour committees) (IDEA, 2002).

Community leadership, especially among indigenous communities, is observed as a key factor to stronger implement authority devolution and decentralization. Likewise, the integration of ideas and projects can strengthen community relations at all levels. This approach generates inclusiveness and it can be used to problem 
solving and decision making as it increases public trust and legitimacy (Suskin, 1995; Swarts, 2000; IDEA, 2002). The CEPA literature also stresses the need to establish frameworks for participatory decision-making that includes the holistic vision to anticipating environmental, economic and social outcomes of socio-economic and ecological challenges (Suskin, 1995; Swarts, 2000; IDEA, 2002; Blaser, 2010). Based on this participatory decision-making framework, community-identities and a shared sense of belonging build the foundation to enabling environment for sustainable development strategies and actions, as well as people's involvement (Blaser, 2009, 2010).

Table 4. CEPA

\begin{tabular}{lcllccc}
\hline Authors & Year & Issue of analysis & Research Trend & CEPA & NRM & FD \\
\hline Blaser, M. & 2009 & Community-Indigenous & $\begin{array}{c}\text { Human Sciences } \\
\text { Humanities }\end{array}$ & $\sqrt{ }$ & $\sqrt{ }$ & - \\
Blaser, M. & 2010 & Community-Indigenous & $\begin{array}{c}\text { Human Sciences } \\
\text { Humanities }\end{array}$ & $\sqrt{ }$ & - & $\sqrt{ }$ \\
& & & & \\
IDEA & 2002 & Economy-Environment & Natural Sciences & $\sqrt{ }$ & $\sqrt{ }$ & - \\
$\begin{array}{l}\text { Susnik, B. } \\
\text { Swarts Frederick A. } \\
\text { Selected Discourses }\end{array}$ & 2095 & Community-Indigenous & Human Sciences & $\sqrt{ }$ & - & - \\
\hline
\end{tabular}

Source: Author's own elaboration

Table 5 displays the corresponding texts of interest on NRM. A primary focus of this literature regards social welfare of local communities as it is frequently connected to the role of community values and beliefs (Swarts, 2000; IDEA, 2002; Danilo et al., 2004; Blaser, 2009). In the context of conservation, the initiatives of local community that are compared reflect the importance of multiculturalism in relation to natural resources and the environment. According to Blaser $(2009,15)$, "having a variety of tools (i.e. different cultures) with which conservation can be realized, whether one uses one or another, is indistinct as long as the environment is affected in the same way". As a result, the take from environmental sustainability is reflected in the inclusion of local knowledge into public and private initiatives. Resources and equity are taken into account in order to describe past and present connections between local economies and conservation (Danilo et al., 2004; Blaser, 2009). Basic needs and fair distribution of local benefits (i.e. compensation for protecting natural resources or regulations on payments for environmental services) are presented as recommendations for the implementation of regulations and sanctions that help the equity of use and management of natural resources (IDEA, 2002; Horton, 2010).

To this regard, what is often considered a central issue is the impact of historical land distribution in the area. For instance, over the past 20 years the role of foreign speculation and dominant economic-political class over land use and distribution in the Pantanal has led to low international prices and unfavourable purchasing conditions (Guereña \& Rojas, 2016). Furthermore, agrarian reforms implemented between 1954 and 2003 shaped the land propriety rights in Paraguay. The effects on the Pantanal resulted in hundreds of land concessions, comprising a total area of 4 million ha part of which were confiscated from local and indigenous ancestral territories. Paraguay's indigenous populations and other impoverished minorities are still harbouring the fear of continuation of the land reform as they work out a legal rights-based mechanism that might replace it (Hetherington, 2009, 236). Hence, linkages between territorialism, identities and the past and present system of land use rights define an important research narrative of NRM. The role of multi-stakeholder inclusion and engagement (i.e. capacity building on conservation strategies, trainings and better management systems) is partly addressed in the creation and implementation of projects for environmental sustainability. This approach is taken to be the NRM element of adaptive leadership and co-management because of the importance given to social-ecological organisations, both local and international, to design programs on adaptive capacity (Gruber, 2010). From this perspective, the resilience of Pantanal's biological diversity has been studied in parallel to the evolution and development of cultural diversities and identities (Swarts, 2000; Blaser, 2009; Horton, 2010).

On a similar note, conflict resolution and cooperation are two connected and recurrent elements of the NRM literature. Although the broad understanding of these two concepts remains merely conceptual and no clear examples can be found, data on community-behaviour can possibly serve as the basis for further development in this regard. For instance, socioeconomic, ethnographic and demographic characteristics of rural and indigenous communities of the Pantanal exist and are widely available (DGEEC, 2002). In addition, NRM strategies should include the analysis of accountability of public and private entities. It is widely agreed that the recognition of the 
central role of institutions outside rural and indigenous communities is a key learning notion of conflict management strategies (Gruber, 2010). However, as for the case described in the Paraguayan Pantanal, the lack of effective and multi-stakeholder inclusive decision making processes tends to prevent the promotion of dialogue and increases factionalism (Hetherington, 2009; Blaser, 2009).

Table 5. NRM

\begin{tabular}{lclcccc}
\hline Authors & Year & Issue of analysis & Research Trend & CEPA & NRM & FD \\
\hline Blaser, M. & 2009 & Community-Indigenous & Human Sciences & $\sqrt{ }$ & $\sqrt{ }$ & - \\
& & & Humanities & & & \\
Danilo A. et al. & 2004 & Biodiversity-Environment & Natural Sciences & - & $\sqrt{ }$ & $\sqrt{ }$ \\
DGEEC & 2004 & Community-Indigenous & Humanities & - & $\sqrt{ }$ & $\sqrt{ }$ \\
IDEA & 2002 & Economy-Environment & Natural Sciences & $\sqrt{ }$ & $\sqrt{ }$ & - \\
Hetherington, K. & 2009 & Economy-Environment & Humanities & - & $\sqrt{ }$ & - \\
Horton Emily Y. & 2010 & Environment & Natural Sciences & - & $\sqrt{ }$ & - \\
& & & Human Sciences & & & \\
Swarts Frederick A. & 2000 & Economy-Environment & Natural Sciences & $\sqrt{ }$ & $\sqrt{ }$ & - \\
\hline
\end{tabular}

Source: Author's own elaboration

Table 6 presents the set of literature searches that, in different ways and forms, were able to produce frameworks developed (FD) from science-based methods. The development of systems of policy, social, and environmental schemes were found to be an important contribution to the analysis of the Paraguayan Pantanal, scaling up proactive solutions for CBNRM. The elaboration of atlas, maps, data systematization and statistical methods represent the kind of FD found in the literature. More specifically, we found valuable information about indigenous communities living in the study area. There are ten linguistic trunks, each of them divided in the corresponding forty ethnic groups and exact location within departments and districts of Argentina, Bolivia, Brazil and Paraguay (Zanardini \& Biedermann, 2001; DGEEC, 2004). Annex 2 shows the different linguistic families and how they are related to their own corresponding ethnic groups and the location according to the country. This systematization, which prioritizes the ethnic criterion over the geographical one, takes into consideration the way of traditional land use and management of indigenous peoples. Hence, it has a statistical scope rather than a legal one and it intends to provide basic information about each of the indigenous settlements that exist in the country.

As the initial research approach, the role of such systems could strengthen the communication and information dissemination of present and future strategies for environmental sustainability. The role played by transparency and openness of information encourages dialogue between experts and non-experts in multiple approaches and forms (i.e. workshops, fundraising opportunities, seminars, training and capacity building etc.). This ultimately helps supporting decision making, learning and change (Gruber, 2010). In parallel with the basics of transparency and openness, the ones on research and information development were described in the FD literature. For instance, the diversification of information topics only regarded discourses of anthropological, ethnographic and biophysical relevance (Zanardini \& Biedermann, 2001; DGEEC, 2004; Danilo et al., 2004; Blaser, 2010). Nonetheless, this is considered as a valid starting point for the production of accessible scientific researches that can influence formal and informal norms to be based upon systematic body of information (Gruber, 2010).

The key element of FD that wasn't found in the literature analysis is one on monitoring, feedback and accountability of science-based and environmental projects. This possibly may be due to the existing low level of openness, transparency, monitoring, mutual accountability, collaboration, and power sharing between stakeholders and partners in the area. Therefore, this factor isn't performed in the selected literature, representing a research gap. To fill this gap, it is recommended that systems of reviewing the performance (i.e. monitoring and evaluation methods) should be promoted to those who make the decision and describe them (Gruber, 2010). Systematic processes of collecting, analysing and using information are useful in tracking the progress of programs (i.e. on environmental sustainability) and science-based researches. 
Table 6. FD

\begin{tabular}{lclcccc}
\hline Authors & Year & Issue of analysis & Research Trend & CEPA & NRM & FD \\
\hline Blaser, M. & 2010 & Community-Indigenous & $\begin{array}{c}\text { Human Sciences } \\
\text { Humanities }\end{array}$ & $\sqrt{ }$ & - & $\sqrt{ }$ \\
Danilo A. et al. & 2004 & Biodiversity-Environment & Natural Sciences & - & $\sqrt{ }$ & $\sqrt{ }$ \\
DGEEC & 2004 & Community-Indigenous & Humanities & - & $\sqrt{ }$ & $\sqrt{ }$ \\
$\begin{array}{l}\text { Zanardini, J., } \\
\text { Biedermann, W. }\end{array}$ & 2001 & Community-Indigenous & Human Sciences & - & - & $\sqrt{ }$ \\
\hline
\end{tabular}

Source: Author's own elaboration

\section{Conclusion}

The conclusion of this synthesis of environmental research knowledge of the Paraguayan Pantanal tropical wetlands lists the dominant research trends and corresponding gaps:

- The branch of natural sciences (both life and physical sciences) was revealed as the main science-based research trend.

- $\quad$ The main gaps were found in the production of frameworks (FD).

Both findings stress the importance to increase and diversify, from both a qualitative and a quantitative perspective, science-based research in the study-area. The reason for it lies beyond the biological and cultural diversity and importance of the site. It has the significance to create, develop, improve and re-shape projects and programs on governance and sustainable development. In this paper, by developing and applying a cluster framework about the concentration of key governance concepts we tried to promote and suggest the inclusion of Gruber's 12 principles for effective and successful CBNRM. In the study of environmental governance, we believe this tool and method can be transferred to other contexts where field-science is scarce. The importance of diversifying science-based researches offers a more holistic perspective where communities are included (CEPA), the use and management of natural resources is more effective (NRM) and a stronger legacy for future studies and interventions is developed (FD).

\section{References}

Agrawal, A., \& Clark, C. G. (1999). Enchantment and Disenchantment: The Role of Community in Natural Resource Conservation. World Development, 27(4), 629-642.

Armitage, D. (2005). Adaptive Capacity and Community-Based Natural Resource Management. Environmental Management, 35(6), 703-15. https://doi.org/10.1007/s00267-004-0076-Z

Blaser, M. (2009). The Threat of the Yrmo : The Political Ontology of a Sustainable Hunting Program. American Anthropological, 111(1), 10-20. https://doi.org/10.1111/j.1548-1433.2009.01073.x

Blaser, M. (2010). Storytelling Globalization from the Chaco and Beyond. Duke University Press. Durham \& London.

Ben, B. (2003). Questioning the Credibility and Capacity of Community-Based Resource Management. The Canadian Geographer / Le Ge 'ographe canadien, 47(2), 137-150

Danilo, A. S. D., Fátima, M., \& Alberto, Y. (2004). Los Humedales de Paraguay. Comité Nacional de Humedales del Paraguay. Asunción, Paraguay.

Dirección General de Estadísticas, Encuestas y Censos (2004). Atlas de las Comunidades indígenas en el Paraguay. Fernando de la Mora, Paraguay.

Gruber, J. S. (2018). Perspectives of Effective and Sustainable Community-Based Natural Resource Management : An Application of Q Methodology to Forest Projects. Conservation and Society, 9(2), $159-71$. https://doi.org/10.4103/0972-4923.83725

Gruber, J. S. (2010). Key principles of community-based natural resource management: A synthesis and interpretation of identified effective approaches for managing the commons. Environmental Management, 45, 52-66.

Guereña, A., \& Rojas V. L. (2016). Yvy Jára. Los dueños de la tierra en Paraguay. Oxfam en Paraguay / Noviembre 2016, Asunción

Hetherington, K. (2009). Privatizing the Private in Rural Paraguay: Precarious Lots and the Materiality of Rights. 
American Ethnologist.

Horton, E. Y. (2010). Gran Pantanal Paraguay. Asociación Guyra Paraguay. Asunción, Paraguay.

Instituto de Derecho y Economía Ambiental (2002). Pantanal Paraguay. IDEA. Asunción, Paraguay.

Leach, M., Mearns, R., \& Scoones, I. (1999). Environmental Entitlements: Dynamics and Institutions in Community-Based Natural Resource Management. Palgrave Macmillan UK, 27(2), 225-247.

Olsson, P., Folke, C., \& Berkes, F. (2004). Adaptive Comanagement for Building Resilience in Social Ecological Systems. Environmental Management, 34(1), 75-90. https://doi.org/10.1007/s00267-003-0101-7

Ostrom, E. (1990). Governing the Commons: The Evolution of Institutions for Collective Action. Cambridge University Press.

Sattler, C., et al. (2016). Multilevel Governance in Community-Based Environmental Management: A Case Study Comparison from Latin America. Ecology and Society, 21(4). https://doi.org/10.5751/ES-08475-210424

Swarts, F. A. (2000). The Pantanal: understanding and preserving the world's largest wetland. Paragon House, St. Paul, Minnesota.

Swarts, F. A. (2000). The Pantanal of Brazil, Bolivia and Paraguay: selected discourses on the world's largest remaining wetland system. Paragon House, St. Paul, Minnesota.

Susnik, B. (1995). Chamacocos: Cambio Cultural. Asunción, Paraguay: Museo Etnográfico Andrés Barbero.

World Wildlife Fund (2016a). Social, economic and environmental analysis of soybean and meat production in Paraguay. Asunción, Paraguay: WWF-Paraguay.

World Wildlife Fund (2016b). Sustaining Landscapes for Life: WWF-Paraguay Strategy to Achieve Greater Conservation Impacts 2016-2020. Asunción, Paraguay: WWF-Paraguay.

Zanardini, J., \& Biedermann, W. (2001). Los indígenas del Paraguay. Asunción, Paraguay: CEADUC.

\section{Annex}

ANNEX 1. Compared literature

Blaser, M. 2009. "The Threat of the Yrmo : The Political Ontology of a Sustainable Hunting Program.” 111(1): 10-20.

Blaser, M. 2010. "Storytelling Globalization from the Chaco and Beyond." Duke University Press, Durham \& London.

Danilo A. Salas Dueñas, Fátima Mereles, Alberto Yanosky 2004. "Los Humedales de Paraguay." Comité Nacional de Humedales del Paraguay. Asunción, Paraguay.

Dirección General de Estadísticas, Encuestas y Censos (DGEEC) 2004. "Atlas de las Comunidades indígenas en el Paraguay". Fernando de la Mora, Paraguay.

Instituto de Derecho y Economía Ambiental (IDEA) 2002. "Pantanal Paraguay". IDEA. Asunción, Paraguay.

Hetherington, K. 2009. "Privatizing the Private in Rural Paraguay: Precarious Lots and the Materiality of Rights." American Ethnologist.

Horton Emily Y. 2010. “Gran Pantanal Paraguay”. Asociación Guyra Paraguay. Asunción, Paraguay.

Susnik, B. 1995. “Chamacocos; Cambio Cultural.”. Asunción, Paraguay: Museo Etnográfico Andrés Barbero.

Swarts Frederick A. 2000. "The Pantanal of Brazil, Bolivia \& Paraguay: Selected Discourses on the World's Largest Remaining Wetland System (Inglés)”. Pasta blanda. Hudson Macarthur Pub Inc.

Swarts Frederick A. 2000: “The Pantanal: understanding and preserving the world's largest wetland.” Paragon House.

Zanardini, J., Biedermann, W. 2001. "Los indígenas del Paraguay”. Asunción, Paraguay: CEADUC.

Source: Author's own elaboration

ANNEX 2. Linguistic families

\begin{tabular}{l}
\hline Abipón, Argentina, historic group \\
Angaite (Angate), northwestern Paraguay \\
Ayoreo (Morotoco, Moro, Zamuco), Bolivia and Paraguay \\
Chamacoco (Zamuko), Paraguay \\
Chané, Argentina and Bolivia \\
Chiquitano (Chiquito, Tarapecosi), eastern Bolivia \\
Chorote (Choroti), Iyojwa'ja Chorote, Manjuy), Argentina, Bolivia, and Paraguay \\
Guana (Kaskihá), Paraguay
\end{tabular}


Guaraní,Argentina, Bolivia, Brazil, and Paraguay

Bolivian Guarani

Chiriguano, Bolivia

Guarayo (East Bolivian Guarani)

Chiripá (Tsiripá, Ava), Bolivia

Pai Tavytera (Pai, Montese, Ava), Bolivia

Tapieté (Guaraní Nandéva, Yanaigua),eastern Bolivia

Yuqui (Bia), Bolivia

Guaycuru peoples, Argentina, Bolivia, Brazil, and Paraguay

Mbayá (Caduveo), historic

Kadiweu, Brazil

Mocoví (Mocobí), Argentina

Pilagá (Pilage Toba)

Toba (Qom, Frentones), Argentina, Bolivia, and Paraguay

Kaiwá, Argentina and Brazil

Lengua people (Enxet), Paraguay

North Lengua (Eenthlit, Enlhet, Maskoy), Paraguay

South Lengua, Paraguay

Lulé (Pelé, Tonocoté), Argentina

Maká (Towolhi), Paraguay

Nivaclé (Ashlushlay, Chulupí, Chulupe, Guentusé), Argentina and Paraguay

Sanapaná (Quiativis), Paraguay

Vilela, Argentina

Wichí (Mataco), Argentina and Bolivia

Source: Zanardini and Biedermann 2001

\section{Copyrights}

Copyright for this article is retained by the author(s), with first publication rights granted to the journal.

This is an open-access article distributed under the terms and conditions of the Creative Commons Attribution license (http://creativecommons.org/licenses/by/3.0/). 